\title{
The effects of feeding procedure on closure of the oesophageal groove in young sheep
}

\author{
By E. R. ØRSKOV, D. BENZIE AND R. N. B. KAY \\ Rowett Research Institute, Bucksburn, Aberdeen $A B 2{ }_{9} S B$
}

(Received 22 December 1969-Accepted 23 March 1970)

\begin{abstract}
I. Barium sulphate suspensions were given to young sheep by mouth or by injection via an oesophageal catheter. Closure of the oesophageal groove was assessed by observing radiographically whether the suspension passed to the ruminoreticulum or to the abomasum.

2. Complete closure of the groove took place in lambs that were trained to drink small meals from a trough after being weaned from their dams, a finding similar to that for lambs weaned on to a teat-bottle.

3. When barium was injected into the oesophagus of lambs that were excited by being offered their bottle or trough beyond their reach, the barium passed direct to the abomasum if the normal feeding routine was closely imitated. When the lambs were able to discriminate between this teasing procedure and the normal routine, the barium frequently passed to the ruminoreticulum. If the lambs were not teased the barium passed invariably to the ruminoreticulum.

4. It is concluded that the reflex closure of the groove can be conditioned by the feeding procedure adopted at weaning so that it no longer depends on the stimuli associated with sucking and swallowing.
\end{abstract}

The oesophageal groove of young ruminants closes while they are sucking their dam and causes swallowed milk to pass direct to the abomasum. In previous experiments (Ørskov \& Benzie, I969) we examined the possibility of using the groove reflex to enable liquid dietary supplements to by-pass the ruminoreticulum, and thus to avoid wasteful fermentation of protein and other nutrients. Radiographs were taken to determine the course taken by different fluids administered to lambs in various ways. It was found that the nature of the fluids tested had no influence on closure of the groove; this was unexpected in view of earlier work which had shown that milk (Wise \& Anderson, 1939) or solutions containing sodium salts (Wester, r930; Trautmann \& Schmitt, I933) or copper sulphate (Watson \& Jarrett, I94I) would promote closure of the groove. It was evidently of great importance that the sheep should be trained to suck from a bottle at weaning and should do so voluntarily and eagerly. Watson (1944) had shown, similarly, that if lambs were trained in this manner milk would continue to pass to the abomasum for months or years.

Our experiments have therefore been extended to examine which stimuli are sufficient to cause closure of the groove. Comline \& Titchen (I95I) demonstrated that in decerebrate calves stimulation of pharyngeal receptors by the swallowing of fluids, or stimulation of the laryngeal nerve, reflexly caused contraction of the muscle of the groove. Nevertheless, is sucking from a teat or the swallowing of fluid a necessary stimulus for closure of the groove in the conscious animal? The first part of this question was answered by training lambs to drink from a trough at weaning, the second part by finding whether the groove closes at feeding time before drinking begins. 


\section{Animals}

The thirteen lambs used were of various breeds; details are given in Table $\mathbf{r}$. Lamb 4774 was a female; the rest were uncastrated males. The lambs were weaned from their dams when about 2 weeks old and were taught to suck cow's milk from a bottle fitted with a teat. At weaning and throughout the experiments the lambs were given dry feed, consisting of rolled barley concentrate and dried grass, ad lib. Drinking water was always available from a trough. They were kept in individual pens, bedded with sawdust, in a large room housing many sheep on various feeding regimens.

\section{Table I. Details of experimental animals}

\begin{tabular}{|c|c|c|c|}
\hline Lamb no. & Breed & Expt no & $\begin{array}{l}\text { Age of animal } \\
\text { during experiment } \\
\text { (months) }\end{array}$ \\
\hline $\left.\begin{array}{l}3997 \\
3998 \\
3999 \\
4000\end{array}\right\}$ & Dorset Horn & $\begin{array}{c}I \text { and } 2 \\
I \text { and } 2 \\
2 \\
I\end{array}$ & $\begin{array}{l}2-7 \\
2-9 \\
2-7 \\
2-4\end{array}$ \\
\hline $\left.\begin{array}{l}4328 \\
4342 \\
4349 \\
4351 \\
4356\end{array}\right\}$ & Suffolk $\times$ Dorset Horn & $\begin{array}{c}3 \\
3 \\
1 \text { and } 3 \\
3 \\
2\end{array}$ & $\begin{array}{l}4-6 \\
4-6 \\
4-7 \\
4-6 \\
3-4\end{array}$ \\
\hline 4426 & Finnish Landrace $\times$ Dorset Horn & I & $2-4$ \\
\hline $\left.\begin{array}{l}4774 \\
4775 \\
4781\end{array}\right\}$ & $\begin{array}{l}\text { Border Leicester } \times \text { Scottish } \\
\text { Blackface }\end{array}$ & $\begin{array}{l}\text { I } \\
\text { I } \\
\text { I }\end{array}$ & $\begin{array}{l}2-4 \\
2-4 \\
2-4\end{array}$ \\
\hline
\end{tabular}

Disorders affected two lambs in Expt 2. Lamb 3997 developed a urethral obstruction. This was relieved by cannulating the bladder so that the last eight radiographs of the series could be completed. Lamb 4356 had to be killed after it had suffered displacement of the abomasum to the left side of the abdominal cavity. Adhesions had developed between the pylorus and the left longitudinal groove of the rumen which evidently obstructed flow through the pylorus, and the abomasum was greatly distended with gas.

\section{Radiography}

The course taken by the liquids administered was determined by radiography. Barium sulphate (Micropaque; Damancy \& Co., Slough, Bucks) was either added to the liquid diet to form a $\mathbf{I}: 6(\mathrm{v} / \mathrm{v})$ suspension or injected through an oesophageal catheter as an undiluted suspension. Right lateral radiographs were taken when the animals were held manually on their sides with the aid of a restraining band, on a table. The table was fitted with a Potter Bucky diaphragm to prevent scattered radiation from reaching the film. The radiographic exposure was $50-55 \mathrm{kV}$ and $32-40 \mathrm{~mA} / \mathrm{s}$ and the focus-film distance $100 \mathrm{~cm}$. Screen films were used together with fast tungstate intensifying screens. 


\section{Procedure}

In all the experiments the lambs were given fluid in a trough or teat-bottle at about 09.30 and I6.00 hours each day. Radiographs were taken, usually on Tuesdays and Fridays, at the time of the morning feed. A summary of the procedures adopted is given in Table 2.

Expt 1 . Eight lambs were used and the observations were made at ages varying from 2 to 9 months. Although weaned on to a teat-bottle, they were later taught to drink milk twice a day, at about 09.30 and 16.00 hours, from a trough. This was accomplished in about $2 \mathrm{~d}$ by allowing the lamb to drink from a teat immersed in the trough during its first few trough feeds. Subsequently six of the lambs were given water from the trough, and two either water or a liquid suspension of yeast. About $300 \mathrm{ml}$ of fluid at about $30^{\circ}$ were given each time.

When radiographs were to be taken, usually twice weekly, the lambs were given their morning trough feed in the usual manner, except that Micropaque was added to the liquid consumed. They were then transported to the radiography room and radiographed 20-30 min after feeding.

Expt 2. Expt I established that, when the lambs drank from a trough in the manner described, the liquid consumed passed direct to the abomasum. A second experiment on four lambs was undertaken to see if the oesophageal groove closed before drinking began. Two of the lambs had been trained to drink from troughs, the other two from bottles. Addition of Micropaque to the fluid drunk in these ways confirmed that it passed direct to the abomasum, as in Expt I.

The state of the groove immediately before drinking was determined by observing the course taken by a small volume of Micropaque injected into an oesophageal catheter. The catheter (Sterivac Polythene Catheter no. 4; Allen and Hanbury) was introduced into the oesophagus under thiopentone anaesthesia a few days before the experiment began. Long forceps were introduced into the oesophagus from the mouth to serve as a guide and pointed forceps were used to pierce an opening into the mid-cervical oesophagus. The catheter was threaded through this opening so that its tip lay at about the level of the first rib, and the external part was secured to the fleece. It was long enough to allow a person to stand behind the lamb and surreptitiously inject the Micropaque without disturbing the animal.

During part I of the experiment the lambs were taken to the radiography room before the procedure associated with feeding was begun so that a preliminary radiograph could be taken. This showed that very little or no barium from the previous trial could be detected in the stomach although sometimes some was present in the large intestine. The lambs were then returned to the sheep-house and their trough or bottle was brought as usual. The trough or bottle was kept just out of reach while I $5 \mathrm{ml}$ Micropaque were injected by way of the oesophageal catheter. This took 20-30 s. The animal was then transported for radiography as in Expt I and was fed in the usual manner when returned to its pen. On the remaining $5 \mathrm{~d}$ of each week the lambs were fed normally.

This procedure was changed when it seemed that the lambs had learned to know 


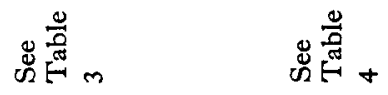

론

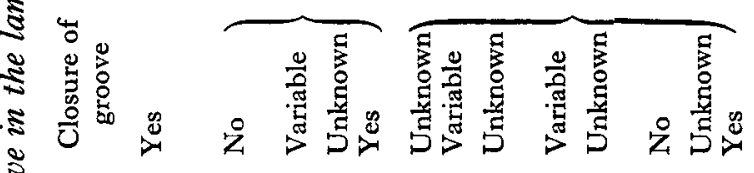

ธิ้

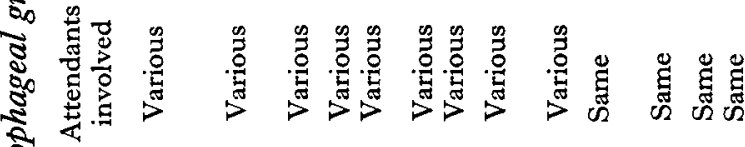

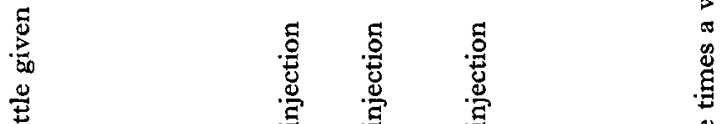

ऽ

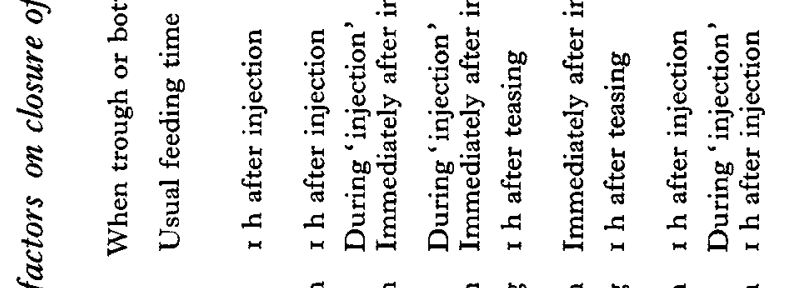

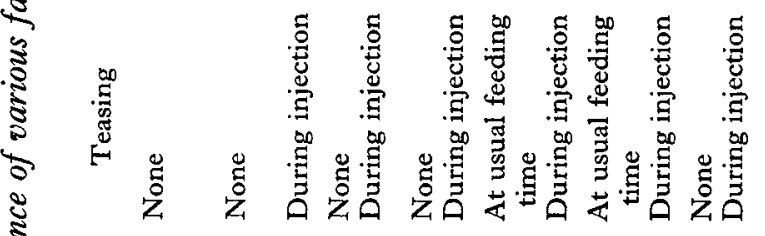

范

艺

ङ

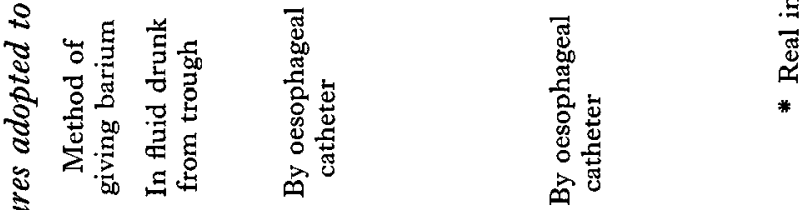

E

¿ุ.

$\frac{\sqrt{3}}{2}$

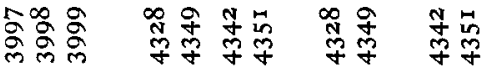

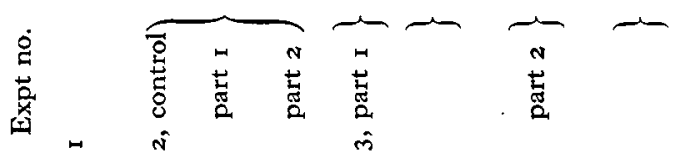


when they were only to be teased with their food, apparently taking as their cue the preliminary radiograph or the presence in their pen of the person giving the injection. In part 2 of the experiment, therefore, no preliminary radiograph was taken before the Micropaque was injected, and the lambs were allowed to drink from the trough or bottle immediately after teasing. To reduce the difference between the procedures adopted on normal and on experimental days, a person entered the lamb's pen each normal day at both feeding times and pretended to give an injection into the oesophageal catheter, though nothing was actually injected.

At three intervals throughout Expt 2 ('control' in Table 2), Micropaque was injected into the oesophagus while the animal was standing quietly in its pen, without being teased or fed.

Expt 3. Expt 2 had shown that the groove closed before drinking when the lambs were being successfully teased with their food, but that this no longer happened regularly once they discovered the deception. Another four lambs were therefore used to examine more fully this ability to discriminate. They were trained to drink from a teat-bottle and were fitted with oesophageal catheters. On the Ist day of the experiment Micropaque was mixed with water and given by bottle. Subsequently, injections of Micropaque were given twice a week while the lambs were teased with their bottle. In part I of the experiment the four lambs were allowed to drink as soon as the injection was completed and were then taken for radiography. No preliminary radiograph was taken. On the remaining days of the week two of the lambs were encouraged to discriminate against the teasing procedure by being teased while their companions were being fed, and were not fed until an hour later. This was intended to extinguish the conditioned closure of the groove associated with the appearance of their feeding bottle. The other two lambs were discouraged from discrimination by being given mock injections, as in Expt 2, while they were being fed. The persons giving the injections and offering the bottle were not the same every day.

These procedures did not lead to consistent differences in response, and so in part 2 of the experiment, when the treatments were reversed, the persons giving the injections (mock or real) and offering the bottle were the same each day. In addition, when injections of Micropaque were given, the lambs were fed an hour later, after radiography, rather than immediately after the injection.

\section{RESULTS}

\section{Expt I}

Altogether twenty-four observations were made on the eight lambs trained to drink from a trough. After training, the animals reacted to the sight of the trough being brought to them in exactly the same manner as they had responded when bottle-fed. They moved excitedly around their pens, jumped up to lean over the door, bleated, often wagged their tails and occasionally made upward butting movements of the head. In every instance the barium suspension they drank was found to have passed to the abomasum and small intestine. None could be detected in the ruminoreticulum although traces were sometimes seen in the omasum. It made no difference when the 
trough was offered nor which person brought it. No effect of age was evident. The time taken to drink $300 \mathrm{ml}$ of fluid was measured with a stop-watch. It took only $8-26 \mathrm{~s}$ to consume this volume from a trough although before trough-training it had taken 22-62 s to drink it from a teat-bottle.

Pl. I A shows the appearance of the abomasum in a trough-fed lamb in which the organ was vigorously contracting when the radiograph was taken. On other occasions it appeared flaccid and elongated, as in Pl. I C, or oriented somewhat transversely as in P1. I D.

\section{Expt 2}

The results of this experiment are summarized in Table 3. Lamb $435^{6}$ has been excluded as only four radiographs were taken before it had to be killed; a large volume of gas was always found in its abomasum, which rendered interpretation of the radiograph uncertain.

\section{Table 3. Expt 2. Influence of teasing lambs with liquid food on closure of the oesophageal groove}

(Closure was judged by determining by radiography the course taken in the stomach by a suspension of barium sulphate which was injected by oesophageal catheter during teasing)

\begin{tabular}{|c|c|c|c|c|c|c|c|}
\hline \multirow{3}{*}{$\begin{array}{l}\text { Part of } \\
\text { Expt }\end{array}$} & \multirow[b]{3}{*}{ Treatment } & \multicolumn{6}{|c|}{$\begin{array}{l}\text { No. of trials in which suspension passed to } \\
\text { ruminoreticulum }(\mathrm{Ru}) \text { or to abomasum (Ab) }\end{array}$} \\
\hline & & \multicolumn{2}{|c|}{ Lamb 3999} & \multicolumn{2}{|c|}{ Lamb 3998} & \multicolumn{2}{|c|}{ Lamb 3997} \\
\hline & & $\mathrm{Ru}$ & $\mathrm{Ab}$ & $\mathrm{Ru}$ & $\mathrm{Ab}$ & $\mathrm{Ru}$ & $\mathrm{Ab}$ \\
\hline Control & $\begin{array}{l}\text { Lambs not teased, or fed immedi- } \\
\text { ately after injection }\end{array}$ & 3 & o & 3 & ० & 3 & 0 \\
\hline$I$ & $\begin{array}{l}\text { Lambs teased; preliminary radio- } \\
\text { graph, no mock injections, no } \\
\text { drink immediately after teasing }\end{array}$ & 3 & $5^{*}$ & 3 & 2 & o & 2 \\
\hline 2 & $\begin{array}{l}\text { Lambs teased; no preliminary } \\
\text { radiograph, mock injections } \\
\text { given, drink immediately after } \\
\text { teasing }\end{array}$ & 0 & $6+$ & $\circ$ & 7 & $\circ$ & $7 \ddagger$ \\
\hline
\end{tabular}

When no preliminary radiographs were taken a little barium might have passed to the ruminoreticulum undetected.

* Traces of barium were apparent in the ruminoreticulum on one occasion.

+ In one additional trial the presence of gas in the abomasum prevented interpretation of the radiograph.

I A large volume of gas was present in the abomasum on three occasions but did not prevent interpretation.

The results of the control trials of this experiment show that, when barium was injected into the remaining three lambs by way of the oesophageal catheter while they were not being teased with food and were standing quietly, the barium invariably passed to the ruminoreticulum. The lambs did not appear to notice the injection. An example is shown in Pl. I B in which the barium had remained confined to the reticulum and anterior rumen. The $20-30 \mathrm{~min}$ that elapsed between injection and radiography usually allowed the barium to diffuse more widely throughout the ruminoreticulum. Comparison with a preliminary radiograph allowed the presence of barium 
in the organ to be positively identified, despite the small amount given, and a faint but clear shadow of the omasum was usually visible. However, in part 2 of the experiment no preliminary radiograph was taken and it was often difficult to decide whether any barium had passed to the rumen. With the lambs held in a lateral position the density of the rumen contents and the position of gas in the organ were variable. Positive identification of barium in the abomasum presented no such difficulties, however. In some additional trials the injection was given as the sheep stood quietly in the radiography room and a radiograph was taken $2-3 \mathrm{~min}$ later; the barium was then visible as a small opacity in the anterior part of the rumen while a trace adhered to the lower oesophagus.

When the lambs were teased with their trough or bottle in part $\mathrm{I}$ of the experiment, they became very excited. Barium injected into the oesophagus while the lambs were being teased in this way often passed direct to the abomasum and intestines. The predictability of this effect depended on the circumstances. When the feeding procedure was irregular, in that a person entered the pen to give an injection only when the lamb was due to be teased, the barium usually passed to the abomasum at the first two or three trials, as shown in Pl. I C, but subsequently it usually passed to the ruminoreticulum. The lambs differed in their ability to learn what was in store for them. Lamb 3998 continued to show normal excited behaviour when teased although the groove no longer always closed. Lambs 3999 and 3997 often rapidly lost interest and appeared dejected while being teased and sometimes turned repeatedly around in their pens in frustration. In part 2 of the experiment a mock or real injection was given every day, no preliminary radiograph was taken before teasing and the lambs were rewarded by a drink after teasing. Under these conditions, barium injected during teasing invariably passed direct to the abomasum. It seemed to make no difference how far away the trough or bottle was held from the lamb, up to $2 \mathrm{~m}$ away, nor (as occasionally happened) whether the lamb succeeded momentarily in reaching the container with its lips.

\section{Expt 3}

The results are shown in Table 4. During part I of the experiment one of the lambs given only real injections directed barium to its abomasum at the first trial, illustrated in P1. I D, but subsequently directed it to the ruminoreticulum, whereas its companion usually directed it to the abomasum throughout. The two lambs given mock injections directed the barium to the ruminoreticulum almost as often as to the abomasum.

After reversal of the treatments (part 2), the barium invariably passed to the ruminoreticulum if mock injections were not given, and to the abomasum if they were given. This improvement in the predictability of the response could probably be ascribed to the presence of the same persons giving the injection and offering the bottle at each trial. In this period no drink was given immediately after the real injection. Despite this added inducement to the lambs to learn when they were merely being teased, they evidently were unable to do so provided that mock injections were given.

In eight of the seventy-six radiographs taken after teasing the lambs in Expts 2 and 3 , the volume of gas in the abomasum was considerably greater than that found in the 
undisturbed lamb. Sometimes this made it difficult to decide at a glance whether the barium had passed to the abomasum or not, though with experience a careful examination allowed a reasonably definite interpretation to be made.

\section{Table 4. Expt 3. Effect of the ability of lambs to discriminate between experimental} conditions on closure of the oesophageal groove during teasing with liquid food

( $\mathrm{Ru}$ indicates that barium sulphate injected into the oesophagus passed to the ruminoreticulum, and $\mathrm{Ab}$ that it passed to the abomasum)

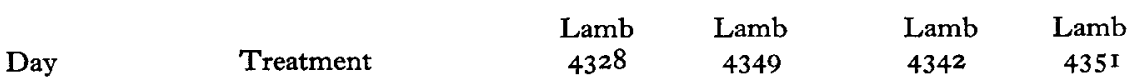

Barium drunk from bottle

I Normal feeding $\quad \mathrm{Ab} \quad \mathrm{Ab} \quad \mathrm{Ab} \quad \mathrm{Ab}$

Barium injected into oesophagus

Part I: Mock injection given

Mock injection not given

3 Teased, drink immediately

$\begin{array}{ll}\mathrm{Ru} & \mathrm{Ru} \\ \mathrm{Ru} & \mathrm{Ab} \\ \mathrm{Ab} & \mathrm{Ab}{ }^{*} \\ \mathrm{Ru} & \mathrm{Ru} \\ \mathrm{Ab} & \mathrm{Ab} \\ \mathrm{Ru}+\mathrm{Ab}^{*} & \mathrm{Ru} \\ \mathrm{Ab} & \mathrm{Ab}\end{array}$
after real injection

Ru

b

$\mathrm{Ru}$

$\mathrm{Ab}$

$\mathrm{Ab}$

Part 2: Mock injection not given

Not teased or fed during injection

Teased, no drink immediately after real injection

$\begin{array}{ll}\overbrace{\mathrm{Ru}} & \mathrm{Ru} \\ \mathrm{Ru} & \mathrm{Ru} \\ \mathrm{Ru} & \mathrm{Ru} \\ \mathrm{Ru} & \mathrm{Ru}\end{array}$

$\begin{array}{ll}\mathrm{Ab} & \mathrm{Ab} \\ \mathrm{Ab} & \mathrm{Ru} \\ \mathrm{Ab} & \mathrm{Ru} \\ \mathrm{Ab} & \mathrm{Ru} \\ \mathrm{Ab}{ }^{*} & \mathrm{Ru} \\ \mathrm{Ru} & \mathrm{Ru} \\ \mathrm{Ab} & \mathrm{Ru}\end{array}$

Mock injection given

$\begin{array}{ll}\overbrace{\mathrm{Ru}}^{\mathrm{Ru}} \\ \mathrm{Ab} & \mathrm{Ab} \\ \mathrm{Ab} & \mathrm{Ab} \\ \mathrm{Ab} * & \mathrm{Ab}\end{array}$

* A large volume of gas was present in the abomasum.

\section{DISCUSSION}

\section{Trough or bottle feeding}

Our experiments show that closure of the oesophageal groove in lambs need not depend on the chemical and mechanical stimuli associated with sucking milk from their dam or from a bottle. Provided the lambs were handled with care and consistency, they could be trained while very young to drink fluids from a trough, when they showed all the excited behaviour of the sucking lamb. In these and other experiments, thirty-four radiographs have been taken of lambs trained to drink small fluid meals from a trough, and about 100 radiographs of lambs trained to a teat-bottle, and in every instance the fluid was found to pass direct to the abomasum. Although lambs drinking from a trough adopted a different posture and drank much more rapidly than did sucking lambs, their grooves closed so efficiently that none of the fluid consumed could be detected in the ruminoreticulum. Lenkeit \& Columbus (1935) have suggested that some fluid may flow back from the abomasum to the ruminoreticulum in young sheep, but this could not be seen in our radiographs. 
The lambs clearly distinguished between the water brought to them in a trough at feeding time and the drinking water always present in an identical trough. The former they consumed with eager excitement, the latter they quietly sipped from time to time. We think this difference in behaviour depended on offering the trough feed occasionally, in small volumes and in a routine manner, while ensuring that drinking water was always freely available so that the lambs did not become thirsty. The trough feed, like a bottle feed (Watson, I944), was evidently accepted as a substitute for suckling and was not associated with the relief of thirst. The precise time of feeding and the presence of other animals with different feeding routines appeared to be relatively unimportant. It was noticed in experiments concerned with the nutritional application of this technique (Ørskov \& Fraser, 1969) that lambs were sometimes hesitant at drinking suspensions of smelly fluids, such as fish-meal solubles, from a trough unless the suspension was introduced gradually. With bottle feeding this was never a problem.

\section{The nature of the reflex}

Expts 2 and 3 established clearly that in trained lambs closure of the groove occurred before drinking began, provided the feeding procedure followed a routine that signalled unequivocally that a fluid meal was about to be given. Apparently reflex closure of the groove, like the excited behaviour of the lamb, was elicited by appropriate visual (and perhaps auditory and olfactory) stimuli and no longer depended on stimulation of buccal and pharyngeal receptors during sucking and swallowing. Although the lambs seemed able to concentrate their attention on the advent of feeding time amid distracting surroundings, complete closure of the groove could not be achieved by forcing the animal to swallow (Ørskov \& Benzie, r969) and restraint was undesirable.

It is unlikely that the injection of $15 \mathrm{ml}$ Micropaque into the upper thoracic oesophagus in itself reflexly affected the groove. When the injection was given while the animal was standing quietly the barium always passed to the ruminoreticulum and never to the abomasum. It is also unlikely that any quantity of barium remained in the oesophagus long enough to be swept up by fluid consumed after the injection was completed. In part 2 of Expt 3, when no drink was permitted immediately after the injection, the barium still passed predictably to the abomasum when conditioning was appropriate.

If given the opportunity, the lambs discriminated between routine feeding and the teasing procedure, and in the latter situation closure of the groove could not be demonstrated before the lamb was allowed to drink. The presence of a person giving the injection into the oesophagus seemed one important cue indicating to the lamb that it was to be teased. Irrespective of other conditions, Micropaque injected during teasing passed to the ruminoreticulum in twenty-one of the thirty-seven trials in which only real injections were given, but only in eight of the forty-two trials in which mock injections were also given. In Expt 3 there was some evidence that the lambs were also able to identify the person attending their bottle. Variation between individual animals was sometimes evident. In subsidiary experiments it was found that, in most lambs trained to the bottle at weaning, reflex closure of the groove took place or could be rapidly re-established after a period of 2 months during which they were 
not fed by bottle. In one ewe, reflex closure of the groove has been maintained during bottle-feeding for over 2 years and this animal has been studied during lactation.

It is well known that young ruminants drinking from a bottle swallow quite large volumes of air which pass to the abomasum (Benzie \& Phillipson, 1957). The gas is only eliminated slowly. While its nutritional significance is unknown, it can scarcely be beneficial. Although little air was swallowed by the lambs that drank from a trough, the teased lambs sometimes swallowed quite large volumes of air and this happened on one occasion, even when no drink was given subsequently. This points to a possible hazard in a feeding routine that allows too long an interval between events that signal feeding time and the actual presentation of the liquid to be drunk.

\section{Applications}

The ability to close the oesophageal groove at will in ruminant lambs, and thus to allow fluid dietary supplements to pass direct to the abomasum, is likely to prove a useful experimental tool for studying the nutrition of ruminants. In particular, our understanding of the digestion of carbohydrate and protein in the intestine has often been hindered by uncertainty concerning the nature and extent of fermentation in the ruminoreticulum. Watson \& Jarrett (1945) described a method for intubation of the abomasum by way of the oesophagus and oesophageal groove, but this was successful in only a small proportion of sheep and so seems unsuitable for routine experimental use.

The value of our technique in practical nutrition is being examined in relation to the intensive rearing of lambs (Ørskov \& Fraser, I969). It offers alternatives to other methods for encouraging food to pass through the rumen unfermented, such as treatment of protein with formalin (Ferguson, Hemsley \& Reis, 1967) and saltinduced acceleration of ruminal outflow (Anonymous, 1968). Our experiments again emphasize the importance of conditioned reflexes in animal management and nutrition (Pavlov, 1927).

\section{REFERENCES}

Anonymous (1968). Rur. Res. C.S.I.R.O. no. 6I.

Benzie, D. \& Phillipson, A. T. (1957). The Alimentary Tract of the Ruminant. Edinburgh and London: Oliver and Boyd.

Comline, R. S. \& Titchen, D. A. (I951). F. Physiol., Lond. II5, 210.

Ferguson, K. A., Hemsley, J. A. \& Reis, P. J. (1967). Aust. F. Sci. 30, 215.

Lenkeit, W. \& Columbus, A. (1935). Arch. wiss. prakt. Tierheilk. 69, 380.

Ørskov, E. R. \& Benzie, D. (I969). Br. F. Nutr. 23, 4I5.

Ørskov, E. R. \& Fraser, C. (1969). F. agric. Sci., Camb. 73, 469.

Pavlov, I. P. (1927). Conditioned Reflexes [O. V. Anrep, translator]. Oxford: University Press.

Trautmann, A. \& Schmitt, J. (1933). Arch. Tierernähr. Tierz. 9, I.

Watson, R. H. (1944). Bull. Commonw. scient. ind. Res. Org. no. ı80, p. I.

Watson, R. H. \& Jarrett, I. G. (I941). Aust. vet. F. 17, 137.

Watson, R. H. \& Jarrett, I. G. (1945). Aust. vet. F. 21, 8.

Wester, I. (1930). Berl. tieräratl. Wschr. 46, I.

Wise, G. H. \& Anderson, G. W. (1939). F. Dairy Sci. 22, 697. 
British Fournal of Nutrition, Vol. 24, No. 3

Plate I
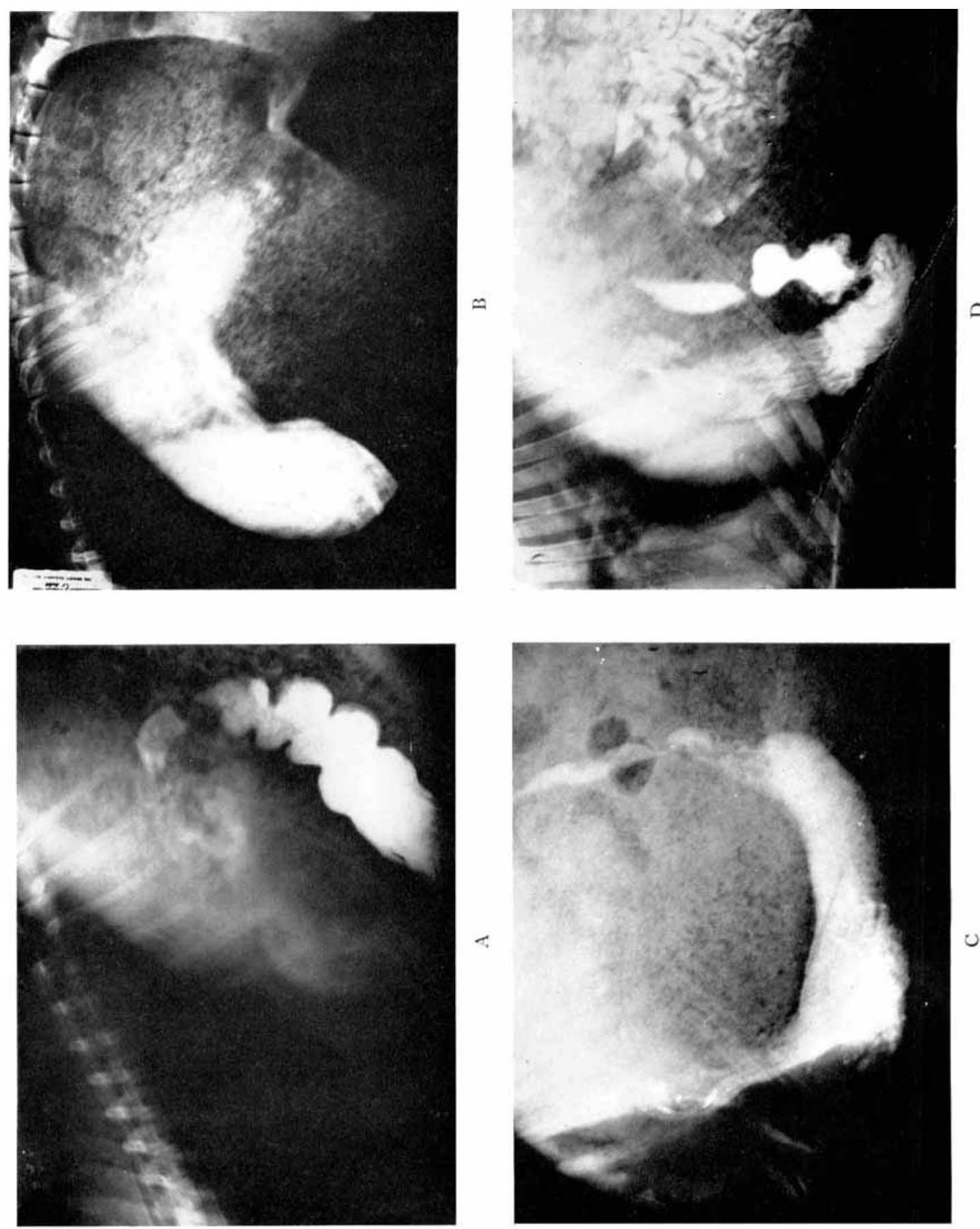

E. R. ORSKOV, D. BENZIE AND R. N. B. KAY

(Facing p. 795) 


\section{EXPLANATION OF PLATE}

Right lateral radiographs (i.e. animal is viewed from left) of lambs after being given either (A) $50 \mathrm{ml}$ barium sulphate (Micropaque; Damancy \& Co., Slough, Bucks) mixed with $300 \mathrm{ml}$ warm water and drunk from a trough, or (B, C, D) $15 \mathrm{ml}$ of the undiluted suspension by injection through an oesophageal catheter. (A) Lamb 3998, 20 min after drinking. Barium was present in the caudal part of the abomasum (which was vigorously contracting) and in the duodenal bulb. (B) Lamb 3999 , 20 min after being injected while standing quietly; its feeding bottle was not offered during or after the injection. Barium has passed to the reticulum and anterior rumen. (C) Lamb 3997, $20 \mathrm{~min}$ after being injected while being teased by being offered its trough beyond its reach; it was allowed to drink $300 \mathrm{ml}$ water from the trough afterwards. Barium was present in the omasum, abomasum and duodenum. (D) Lamb 435 I, 32 min after being injected while being teased by being offered its feeding bottle beyond its reach; no drink was allowed immediately after teasing. Barium was present in the omasum, abomasum (which was vigorously contracting) and duodenal bulb; barium had also passed to the intestine. 